\title{
Biologically-Effective-Dose of Tolpyralate and Tolpyralate plus Atrazine for Control of Multiple-Herbicide-Resistant Waterhemp [Amaranthus tuberculatus (Moq.) J. D. Sauer] in Corn
}

\author{
Christian Willemse ${ }^{1}$, Nader Soltani ${ }^{*}$, Brendan Metzger ${ }^{1}$, David C. Hooker ${ }^{1}$, Amit J. Jhala ${ }^{2}$, \\ Darren E. Robinson', Peter H. Sikkema ${ }^{1}$
}

${ }^{1}$ Department of Plant Agriculture, University of Guelph, Ridgetown, ON, Canada

${ }^{2}$ Department of Agronomy and Horticulture, University of Nebraska-Lincoln, Lincoln, NE, USA

Email: *soltanin@uoguelph.ca

How to cite this paper: Willemse, C., Soltani, N., Metzger, B., Hooker, D.C., Jhala, A.J., Robinson, D.E. and Sikkema, P.H. (2021) Biologically-Effective-Dose of Tolpyralate and Tolpyralate plus Atrazine for Control of Multiple-Herbicide-Resistant Waterhemp [Amaranthus tuberculatus (Moq.) J. D. Sauer] in Corn. Agricultural Sciences, 12, 424-443. https://doi.org/10.4236/as.2021.124028

Received: March 26, 2021

Accepted: April 25, 2021

Published: April 28, 2021

Copyright $\odot 2021$ by author(s) and Scientific Research Publishing Inc. This work is licensed under the Creative Commons Attribution International License (CC BY 4.0).

http://creativecommons.org/licenses/by/4.0/

\begin{abstract}
The biologically-effective-dose of tolpyralate, a new 4-hydroxyphenyl-pyruvate dioxygenase (HPPD)-inhibitor, applied alone or tank-mixed with atrazine, for the control of multiple-herbicide-resistant (MHR) waterhemp [Amaranthus tuberculatus (Moq.) J. D. Sauer] has not been studied in corn. Seven field experiments were conducted during a three-year period $(2018,2019,2020)$ in Ontario, Canada with MHR waterhemp to determine: 1) the dose-response of MHR waterhemp to tolpyralate and tolpyralate plus atrazine, and 2) the relative efficacy of tolpyralate and tolpyralate plus atrazine to post-emergence corn herbicides, dicamba/atrazine $\left(500 / 1000 \mathrm{~g} \cdot \mathrm{ha}^{-1}\right)$ and mesotrione + atrazine $\left(100+280 \mathrm{~g} \cdot \mathrm{ha}^{-1}\right)$. Tolpyralate + atrazine $\left(120+4000 \mathrm{~g} \cdot \mathrm{ha}^{-1}\right)$ caused $13 \%$ corn injury at one site two weeks after application (WAA), which was observed as transient foliar chlorosis and bleaching of new leaves. At 12 WAA, the predicted dose of tolpyralate for $50 \%$ control of MHR waterhemp at Cottam and on Walpole Island was 8 and 2 g.ha ${ }^{-1}$, respectively; the predicted dose of tolpyralate + atrazine for 50\% control of MHR waterhemp at Cottam

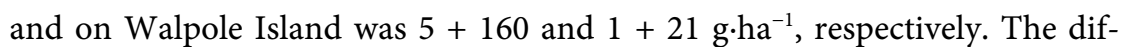
ference in predicted dose at the two sites is likely due to differences in MHR density and resistance profile. Applied at the registered rate, tolpyralate (30 $\left.\mathrm{g} \cdot \mathrm{ha}^{-1}\right)$ and tolpyralate + atrazine $\left(30+1000 \mathrm{~g} \cdot \mathrm{ha}^{-1}\right)$ controlled MHR waterhemp similar to dicamba/atrazine and mesotrione + atrazine across sites. This study demonstrates that tolpyralate + atrazine, applied POST, provides season-long control of MHR waterhemp in corn.
\end{abstract}




\section{Keywords}

Biological Effective Dose, Biomass, Density, Multiple-Herbicide-Resistant, Weed Management

\section{Introduction}

Waterhemp (Amaranthus tuberculatus (Moq.) J.D. Sauer) is a summer-annual, broadleaf weed species found in agricultural cropping systems across the mid-western United States. Waterhemp has been documented in 19 states of the United States and three Canadian provinces including Ontario [1] [2]. The spread of waterhemp across Ontario and its ability to proliferate in corn production are facilitated by several biological characteristics, which include a prolonged emergence pattern, rapid growth rate, dioecious reproductive system, and prolific seed production [3] [4] [5]. Waterhemp seeds germinate in a wide range of environmental conditions resulting in multiple waterhemp flushes throughout the growing season; in Ontario, waterhemp emerges from May through October [6] [7] [8] [9]. Once emerged, waterhemp exhibits an aggressive, indeterminate growth habit allowing it to compete with agricultural crops and reach over $3 \mathrm{~m}$ in height in competitive environments [3] [10]. Waterhemp typically produces 300,000 seeds per plant when competing with a growing crop; however, a plant can produce up to 4.8 million seeds, contributing vast quantities of seed to the soil seed bank [4].

Waterhemp is an obligate cross-pollinating weed species that experiences massive gene flow amongst populations [3] [11] [12]. The introgression of genetic material enables waterhemp populations to thrive across a wide range of environments and growing conditions and allows plants to stack traits that confer resistance to numerous herbicide modes of action (MOA) [3] [13]. In waterhemp, resistance has been identified to the synthetic auxins, acetolactate synthase (ALS)-, photosystem II (PS II)-, 5-enolpyruvylshikimate-3-phosphate synthase (EPSPS)-, protoporphyrinogen oxidase (PPO)-, very-long-chain fatty-acid (VLCFA)-, and 4-hydoxyphenylpyruvyl dioxygenase (HPPD)-inhibitors [1] [14] [15]. Waterhemp continues to rapidly evolve herbicide resistance and is the first weed species known to evolve resistance to the HPPD-inhibitors [14]. The first multiple-herbicide-resistant (MHR) waterhemp population resistant to six herbicide MOA including the synthetic auxins, ALS-, PS II-, EPSPS-, PPO-, and HPPD-inhibitors was identified in 2015 in Missouri [15]. In Ontario, waterhemp populations containing individuals exhibiting four-way resistance to ALS-, PS II-, EPSPS-, and PPO-inhibitors have been reported [2]. Additionally, $80 \%$ of these populations have three-way multiple resistance to ALS-, PS II-, and EPSPS-inhibitors. The dioecious and anemophilous biology, coupled with the potential for pollen-mediated gene flow in waterhemp enables transfer of herbicide resistance alleles among populations [16], further complicating manage- 
ment of this species with herbicides [12] [17].

Herbicide-resistance enables waterhemp to escape weed control measures in corn production [3]. When left uncontrolled, waterhemp can reduce corn yield up to $74 \%$ [18]. In Ontario, corn yield loss up to $48 \%$ has been reported [19]. Corn should be kept weed-free from emergence (VE) to the V6 corn stage to prevent yield loss caused by waterhemp interference [18]. Waterhemp cohorts that emerge after V6 may not reduce corn yield; however, full-season MHR waterhemp control is prudent to prevent soil seed bank replenishment [4] [18]. Season-long MHR waterhemp control can be achieved with herbicide tank-mixtures applied preemergence (PRE), PRE followed by postemergence (POST), early postemergence (ePOST), or POST [20]-[25]. The HPPD-inhibitors, such as bicyclopyrone, isoxaflutole, mesotrione, tembotrione, and topramezone exhibit excellent activity on MHR waterhemp and can be applied PRE, ePOST, or POST [20] [26] [27] [28] [29] [30]. The HPPD-inhibitors are often applied in a tank-mixture with a PS II-inhibitor such as atrazine due to complementary activity between these MOA [19] [20] [21] [25]. Complementary activity between the HPPD-inhibitors and atrazine has been reported for the control of triazinesusceptible and triazine-resistant redroot pigweed (Amaranthus retroflexus L.), Palmer amaranth (Amaranthus palmeri S. Watson), and waterhemp [31] [32] [33]. In plants, HPPD-inhibitors prevent the production of $\alpha$-tocopherols, plastoquinone, and carotenoids that protect cells from reactive oxygen species (ROS) generated during photosynthesis, while PS II-inhibitors enhance the production of ROS by inhibiting electron transfer [34] [35]. Enhanced weed control results from the application of HPPD-inhibitors + atrazine due to: 1) increased binding efficiency of atrazine caused by the shortage of plastoquinone and 2) the accumulation of ROS due to the shortage of quenching antioxidants $\alpha$-tocopherols, plastoquinone, and carotenoids. The application of HPPD-inhibitors + atrazine results in excellent season-long control of MHR waterhemp [20] [21] [25] [28].

Tolpyralate is a relatively new HPPD-inhibitor that controls several annual grass and broadleaf weed species [27] [36]. Previous Ontario studies report excellent control of Amaranthus species with tolpyralate and EPSPS-resistant waterhemp with tolpyralate + atrazine [36] [37] [38] [39]. In the United States, the commercial label for tolpyralate states control of both $A$. rudis and A. tuberculatus at the 30 to $40 \mathrm{~g} \cdot \mathrm{ha}^{-1}$ rate, while the Canadian label states suppression of $A$. rudis [40] [41]. The $A$. tuberculatus biotype is native to undisturbed habitats in southern Ontario and Western Quebec, while $A$. rudis is thought to be introduced into Ontario from the United States [3]. For the purpose of this research, the Weed Science Society America designation waterhemp (A. tuberculatus) refers to both tall (A. tuberculatus var. tuberculatus) and common (A. tuberculatus var. rudis) waterhemp [42]. The efficacy of tolpyralate on MHR waterhemp has not been reported; however, other HPPD-inhibitors provide excellent control. Therefore, it is hypothesized that the POST application of tolpyralate and tolpyralate + atrazine will result in season-long control of MHR waterhemp. The objectives of 
this study were to determine the biologically-effective dose of POST-applied tolpyralate and tolpyralate + atrazine for control of MHR waterhemp, and to determine the relative efficacy of tolpyralate and tolpyralate + atrazine in comparison to POST herbicides for control of MHR waterhemp in corn in Ontario.

\section{Materials and Methods}

\subsection{Experimental Methods}

Field trials were conducted near Cottam, ON, Canada $\left(42.149076^{\circ} \mathrm{N}\right.$, $\left.-82.683687^{\circ} \mathrm{W}\right)$ and on Walpole Island, ON, Canada $\left(42.561492^{\circ} \mathrm{N}\right.$, $\left.-82.501487^{\circ} \mathrm{W}\right)$ in 2018,2019 , and 2020 . The presence of MHR waterhemp populations resistant to ALS-, PS II-, EPSPS-, and PPO-inhibitors was confirmed during each year of study by establishing permanent quadrat experiments at each trial: eight quadrats were treated POST with either imazethapyr (BASF Canada Inc. 100 Milverton Drive, Mississauga, ON) $\left(100 \mathrm{~g} \mathrm{ai} \mathrm{ha}^{-1}\right)+$ Agral $^{\circledR} 90$ (Syngenta Canada Inc., 140 Research Lane, Research Park, Guelph, ON) (0.2\% v/v) + urea ammonium nitrate (UAN 28-0-0) (Sylvite, 3221 North Service Road, Burlington, ON) (2.5\% v/v), atrazine (Syngenta Canada Inc., 140 Research Lane, Research Park, Guelph, ON) (1500 g ai ha $\left.{ }^{-1}\right)+$ Assist $^{\circledR}$ oil concentrate (BASF Canada Inc., 100 Milverton Drive, Mississauga, ON) (1\% v/v), glyphosate (Bayer CropScience Inc., 160 Quarry Park Blvd SE, Calgary, AB) (900 g ae ha ${ }^{-1}$ ); or fomesafen (Syngenta Canada Inc. 140 Research Lane, Research Park, Guelph, ON) $\left(240 \mathrm{~g}_{\text {ai ha }}{ }^{-1}\right)+$ Agral 90 (Syngenta Canada Inc., 140 Research Lane, Research Park, Guelph, ON) $(0.2 \% \mathrm{v} / \mathrm{v})$. The percent of individuals resistant to each MOA were calculated using the number of surviving plants within each quadrat at 3 weeks after application (WAA) and is presented in Table 1.

The previous crop at each trial site was either corn or soybean. In the spring, trial sites were fertilized according to soil test results and crop requirements and cultivated twice with a tandem disc to prepare the seedbed for planting. Dekalb DKC46-82RIB corn (Monsanto Co., St. Louis, MO) was seeded $4.5 \mathrm{~cm}$ deep in plots which were $2.25 \mathrm{~m}$ wide and $8 \mathrm{~m}$ long, on $0.75 \mathrm{~m}$ row spacing at a population of 83,140 seeds $\mathrm{ha}^{-1}$. Treatments were arranged in a randomized complete block with four replications. Shortly after crop emergence, potassium salt of glyphosate was applied to the entire experimental area to remove EPSPS-inhibitor susceptible waterhemp and non-target weed species. Treatments were applied when MHR waterhemp plants reached an average of $10 \mathrm{~cm}$ in height, using a $\mathrm{CO}_{2}$-pressurized backpack sprayer and a handheld spray boom outfitted with four ULD120-02 nozzles (Pentair, $3755^{\text {th }}$ Ave NW, New Brighton, MN) spaced $50 \mathrm{~cm}$ apart. For the dose response analysis, six rates of tolpyralate (Shieldex 400SC, ISK Biosciences Corporation, 740 Auburn Road, Concord, OH) (3.75, 7.5, 15, 30, 60 and $120 \mathrm{~g} \cdot \mathrm{ha}^{-1}$ ) were applied alone, and in a 1:33.3 tank-mixture with atrazine at rates 125, 250, 500, 1000, 2000 and $4000 \mathrm{~g} \cdot \mathrm{ha}^{-1}$ similar to [38]. Methylated seed oil (MSO Concentrate ${ }^{\circledR}$ ) (Loveland Products, 3005 Rocky 
Table 1. Year, location, waterhemp resistance, spray date, corn growth stage, waterhemp (Amaranthus tuberculatus) height and density at application, and corn planting and harvest date for seven field experiments conducted in Ontario, Canada in 2018, 2019, and 2020 .

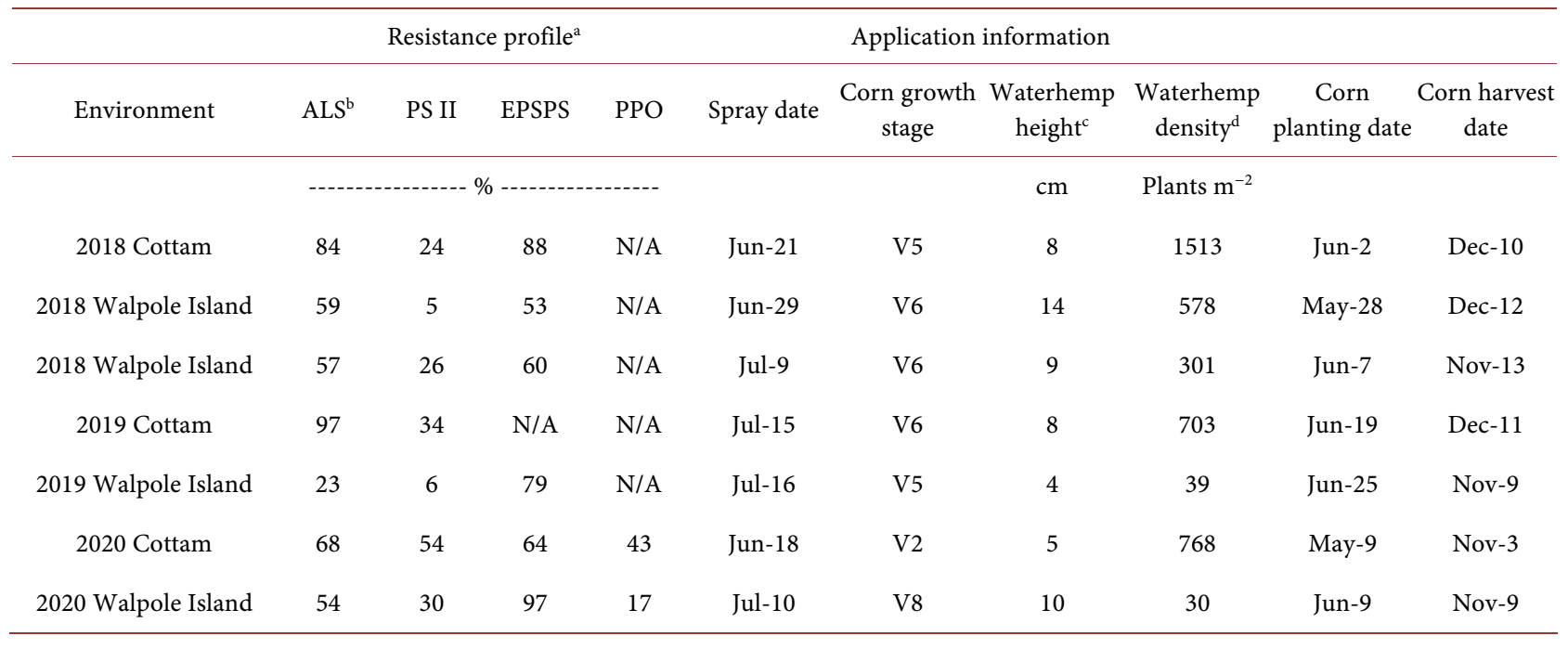

${ }^{a}$ Mean number of surviving waterhemp plants three weeks after application divided by the number of waterhemp plants sprayed within eight quadrates per site. 'Herbicide mode of action classification (Weed Science Society of America); ALS, acetolactate synthase; PS II, photosystem II; EPSPS, 5-enolpyruvylshikimate-3-phosphate synthase; PPO, protoporphyrinogen oxidase. ${ }^{\mathrm{C}}$ Mean height based on two or more measurements per replication within each trial at the time of treatment application. ${ }^{\mathrm{d}}$ Mean density based on two random stand counts in each non-treated control plot within each trial.

Mountain Ave., Loveland, $\mathrm{CO}$ ) and UAN were included with each tolpyralate application at $0.50 \% \mathrm{v} / \mathrm{v}$ and $2.50 \% \mathrm{v} / \mathrm{v}$, respectively. Comparison POST herbicides included a pre-mixture (1:2 ratio) of dicamba/atrazine (Marksman ${ }^{\circledR} \mathrm{Her}$ bicide, BASF Canada Inc. Mississauga, ON) (500/1000 g.ha $\left.{ }^{-1}\right)$ and tank-mixture of mesotrione + atrazine (Syngenta Canada Inc., 140 Research Lane, Research Park, Guelph, ON $)\left(100+280\right.$ g.ha $\left.{ }^{-1}\right)$. Mesotrione + atrazine applications included a nonionic surfactant $\left(\mathrm{Agral}^{\circledR} 90\right)$ at $0.20 \% \mathrm{v} / \mathrm{v}$ in accordance with label recommendations [43]. Additionally, each replicate included a nontreated control, and a weed-free control that was established using a pre-formulated mixture of $S$-metolachlor/mesotrione/bicyclopyrone/atrazine (588/35/140/1259 g.ha ${ }^{-1}$ ) (Acuron $^{\mathrm{TM}}$ Herbicide) (Syngenta Canada Inc., 140 Research Lane, Research Park, Guelph, ON) applied PRE, followed by dicamba/atrazine (500/1000 g.ha-1) applied POST, with subsequent hand-weeding where required.

Corn injury was evaluated 1, 2, and 4 WAA, and weed control was evaluated $2,4,8$, and 12 WAA based on $0 \%$ to $100 \%$ rating where $0 \%$ represents no visible crop injury/weed control and $100 \%$ represents complete plant death. Waterhemp density (plants $\mathrm{m}^{-2}$ ) and dry biomass $\left(\mathrm{g} \cdot \mathrm{m}^{-2}\right.$ ) were determined in each plot 8 WAA by randomly placing two, $0.25 \mathrm{~m}^{-2}$ quadrats in the centre row of each plot, counting, and cutting the waterhemp plants at the soil surface contained in each quadrat, and drying the harvested biomass to constant mass at $60^{\circ} \mathrm{C}$. Corn grain yield $\left(\mathrm{kg} \cdot \mathrm{ha}^{-1}\right)$ was taken from the center two rows of each plot by harvesting with a small-plot combine and weighing the sample. Corn grain yield was corrected to $15.5 \%$ moisture prior to the statistical analysis. 


\subsection{Statistical Analysis}

Data were subjected to variance analysis using the GLIMMIX procedure in SAS v. 9.4 (SAS Institute, Cary, NC). An initial mixed model analysis was conducted to evaluate site-by-treatment interactions. The fixed effect was treatment and the random effects were site, site-by-treatment, and replication within site. Site-by-treatment interactions were significant $(\mathrm{P}<0.05)$ with no differences within Cottam locations, and Walpole Island locations; therefore, data were analyzed and presented separately for the Cottam and Walpole Island sites.

\subsubsection{Regression Analysis}

Waterhemp control at 2, 4, 8, and 12 WAA, waterhemp density and dry biomass, and relative corn grain yield were regressed against the dose of tolpyralate applied alone, and tolpyralate + atrazine, by fitting either one of two equations to the data using the NLIN procedures in SAS v. 9.4 (SAS Institute, Cary, NC). The following equations were used for the regression analysis.

Rectangular hyperbolic equation [44]:

$$
y=(b * \text { dose }) / 1+(b * \text { dose } / a)
$$

where

$$
\begin{aligned}
& a=\text { upper asymptote } \\
& b=\text { initial slope }
\end{aligned}
$$

Exponential decay equation:

$$
y=a+b * e^{(-c * \text { dose })}
$$

where

$$
\begin{aligned}
& a=\text { lower asymptote } \\
& b=\text { change in } y \text { from intercept to } a \\
& c=\text { slope from intercept to } a
\end{aligned}
$$

Predicted values generated from the regression analysis were used to compute the expected dose $\left(\mathrm{ED}_{\mathrm{n}}\right)$ of tolpyralate or tolpyralate + atrazine for $50 \%, 80 \%$, and $95 \%$ control, a $50 \%, 80 \%$ and $95 \%$ reduction in density and dry biomass (relative to the nontreated control) and to achieve 50\%, 80\%, and 95\% of the yield of weed-free control plots within each replicate. Where computation of the required dose was not possible with the regression model, values are substituted with non-estimable "Non-est." in Tables.

\subsubsection{Variance Analysis and Least-Square Means Comparisons}

A generalized linear mixed-model analysis was performed on each variable for the purpose of comparing specific treatments including tolpyralate applied at a label rate alone or with atrazine, mesotrione + atrazine, and dicamba/atrazine, using the GLIMMIX procedure in SAS v. 9.4 (SAS Institute, Cary, NC). The nontreated control was excluded from analysis of visible control data, as control was assumed to be zero. Variance was partitioned into the random effects of environment, replication within environment, and the treatment by environment 
interaction, while treatment was designated as the fixed effect. The significance of random effects was determined with a log-likelihood ratio test, and fixed effects using an F-test, with a significance level of 0.05 for all tests. An appropriate model was assigned to each response parameter based on the distribution and link which best met assumptions that residuals had a mean of zero, were homogeneous, and were normally distributed, according to a Shapiro-Wilk test and visual inspection of scatterplots of studentized residuals. Control data and grain yield were modelled using a normal distribution with identity link; MHR waterhemp density and biomass were fit to a lognormal distribution. Where a lognormal distribution was specified, the data were back-transformed using the omega method (M. Edwards, Ontario Agricultural College Statistician, University of Guelph, personal communication). Least-square means of each parameter were compared across treatments using a Tukey-Kramer test and assigned letter codes for presentation.

\section{Results and Discussion}

MHR waterhemp control with tolpyralate and tolpyralate + atrazine varied by site. Across 2, 4, 8, and 12 WAA, control of MHR waterhemp with tolpyralate and tolpyralate + atrazine ranged from $60 \%$ to $99 \%$. Control was lower at Cottam due to greater waterhemp density and biomass and differences in the resistance profile compared to Walpole Island (Table 4 and Table 7). The density and biomass of MHR waterhemp for the nontreated control at Cottam was 740 plants $\mathrm{m}^{-2}$ and $390 \mathrm{~g} \cdot \mathrm{m}^{-2}$ compared to 69 plants $\mathrm{m}^{-2}$ and $99 \mathrm{~g} \cdot \mathrm{m}^{-2}$ on Walpole Island, respectively. All MHR waterhemp populations were resistant to ALS-, PS II-, EPSPS-, and PPO-inhibitors; however, Cottam contained a higher proportion of ALS-, PS II-, and PPO-resistant individuals (Table 1). Similarly, Vyn et al. [25] reported greater control of an ALS-resistant waterhemp population compared to an ALS- and PS II-resistant population. In that study, greater waterhemp density and biomass resulted in lower waterhemp control [25].

\subsection{Corn Injury}

On average, most treatments caused $<5 \%$ corn injury; tolpyralate + atrazine at the highest dose $\left(120+4000 \mathrm{~g} \cdot \mathrm{ha}^{-1}\right)$, caused $13 \%$ injury 2 WAA at Cottam in 2018 (data not shown). Where injury did occur, symptoms consisted of temporary white bleaching and blotched chlorosis of the youngest corn leaves unfurled at the time of application. Corn injury was transient and diminished to $<10 \%$ by 4 WAA. Greater injury was observed where applications of tolpyralate + atrazine were made under high ambient temperature $\left(27^{\circ} \mathrm{C}\right)$ following a period of excessive rainfall that caused temporary flooding (data not shown). Environmental variables such as temperature, precipitation, and application timing affect the activity of tolpyralate and other HPPD-inhibitors [39] [45]. Johnson and Young [45] reported greater foliar activity with mesotrione in some weed species when applied at a relatively high temperature $\left(32^{\circ} \mathrm{C}\right)$, compared with applications 
made at a lower temperature $\left(18^{\circ} \mathrm{C}\right)$. Similarly, [39] reported greater corn injury 1 WAA with tolpyralate + atrazine applications made earlier in the day compared to later in the day, at higher temperatures, and at a larger temperature differential (daily high-daily low) during the 24 hours preceding application. In contrast, [39] reported higher cumulative precipitation during the week following application reduced corn injury from tolpyralate + atrazine which was likely due to the alleviation of pre-existing moisture stress. Therefore, it is possible that the combination of environmental stressors at Cottam predisposed the corn to herbicide injury.

\subsection{Dose Response}

The POST application of tolpyralate alone caused white bleaching in the growing point of waterhemp plants 1 WAA, while tolpyralate + atrazine induced greater leaf bleaching and necrosis at this timing (data not shown). Similar observations were made in a previous study of the biologically-effective-dose of tolpyralate in a mixed population of green pigweed (Amaranthus powelli $\mathrm{S}$. Watson) and redroot pigweed [38]. At Cottam, the predicted dose of tolpyralate for 50\% MHR waterhemp control at 2, 4, 8 and 12 WAA and 50\% reduction in density and biomass was 4 to $8 \mathrm{~g} \cdot \mathrm{ha}^{-1}$; the predicted dose for $80 \%$ or $95 \%$ MHR waterhemp control or an $80 \%$ or $95 \%$ reduction in density and biomass was non-estimable (Table 2). The predicted dose of tolpyralate to achieve $50 \%$ and $80 \%$ of the yield of the weed-free control was 1 and $31 \mathrm{~g} \cdot \mathrm{ha}^{-1}$, respectively. In contrast, on Walpole Island, the predicted dose of tolpyralate for $50 \%, 80 \%$, and 95\% MHR waterhemp control, reduction in density and reduction in biomass was 2,6 , and 29; 3, 7, and 15 and 2, 5, and $9 \mathrm{~g} \mathrm{ha}^{-1}$, respectively at 8 WAA (Table 5). The predicted dose of tolpyralate to achieve $95 \%$ of the corn grain yield of the weed-free control was $3 \mathrm{~g} \cdot \mathrm{ha}^{-1}$.

At Cottam, the predicted dose of tolpyralate + atrazine for 50\%, 80\%, and 95\% MHR waterhemp control was $4+136,20+671 \mathrm{~g} \cdot \mathrm{ha}^{-1}$, and non-estimable, respectively at 2 WAA (Table 3 ). The predicted dose of tolpyralate + atrazine for $50 \%$ and $80 \%$ MHR control at 2, 4, 8, and 12 WAA increased slightly with time. The predicted dose of tolpyralate + atrazine for a $50 \%, 80 \%$, and $95 \%$ reduction in MHR waterhemp density was $3+113,10+339$, and non-estimable, respectively. The predicted dose of tolpyralate + atrazine to achieve $50 \%$ and $80 \%$ of the yield of the weed-free control was $1+35$ and $8+263 \mathrm{~g} \cdot \mathrm{ha}^{-1}$, respectively. In contrast, on Walpole Island, the predicted dose of tolpyralate + atrazine for $50 \%$, $80 \%$, and $95 \%$ MHR waterhemp control was $1+41,5+176$, and $42+1432$ g.hat ${ }^{-1}$, respectively at 2 WAA (Table 6 ). The predicted dose of tolpyralate + atrazine for $50 \%, 80 \%$ and $95 \%$ MHR control at 2, 4, 8, and 12 WAA decreased with time. The predicted dose of tolpyralate + atrazine for a 50\%, $80 \%$, and $95 \%$ reduction in MHR waterhemp density was $2+68,5+161$ and $10+331$, respectively. The predicted dose of tolpyralate + atrazine to achieve $95 \%$ of the corn grain yield of the weed-free control was $4+119 \mathrm{~g} \cdot h \mathrm{ha}^{-1}$. 
Table 2. Regression parameters and the predicted dose of tolpyralate required to obtain $50 \%, 80 \%$, and $95 \%$ control of multiple-herbicide-resistant waterhemp (Amaranthus tuberculatus) 2, 4, 8, and 12 weeks after application (WAA), a 50\%, 80\%, and 95\% reduction in density and biomass, and $50 \%, 80 \%$, and $95 \%$ of the corn grain yield in weed-free control plots, from three field experiments conducted near Cottam, Ontario, Canada in 2018,2019 , and 2020.

\begin{tabular}{|c|c|c|c|c|c|c|}
\hline \multirow[b]{2}{*}{ Variable } & \multicolumn{3}{|c|}{ Regression parameters $^{\mathrm{a}}( \pm \mathrm{SE})$} & \multicolumn{3}{|c|}{ Predicted tolpyralate dose } \\
\hline & $a$ & $b$ & $c$ & $\mathrm{ED}_{50}$ & $\mathrm{ED}_{80}$ & $\mathrm{ED}_{95}$ \\
\hline Control & \multicolumn{3}{|c|}{ 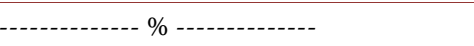 } & \multicolumn{3}{|c|}{ - } \\
\hline 2 WAA & $75(1.9)$ & $29(3.8)$ & - & 5 & Non-est. & Non-est. \\
\hline 4 WAA & $70(2.1)$ & $28(4.5)$ & - & 6 & Non-est. & Non-est. \\
\hline 8 WAA & $71(2.6)$ & $21(3.6)$ & - & 8 & Non-est. & Non-est. \\
\hline \multirow[t]{2}{*}{12 WAA } & $73(3.1)$ & $21(4.2)$ & - & 8 & Non-est. & Non-est. \\
\hline & \multicolumn{2}{|c|}{------ Plants $\mathrm{m}^{-2}$------- } & & & & \\
\hline \multirow[t]{2}{*}{ Density } & $236(55.1)$ & $514(116.5)$ & $0.23(0.12)$ & 6 & Non-est. & Non-est. \\
\hline & \multicolumn{2}{|c|}{ - $\mathrm{g} \cdot \mathrm{m}^{-2}-\mathrm{c}$} & & & & \\
\hline Biomass & $79(13.1)$ & $290(28.5)$ & $0.26(0.06)$ & 4 & Non-est. & Non-est. \\
\hline Grain yield & $82(4.6)$ & $116(86.9)$ & - & 1 & 31 & Non-est. \\
\hline
\end{tabular}

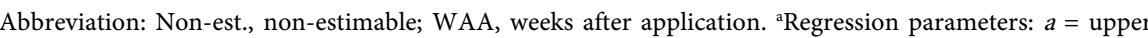
asymptote of control and yield or lower asymptote of density and biomass, $b=$ initial slope of control and yield or reduction in $y$ from intercept to asymptote of density and biomass, $c=$ slope from intercept to lower asymptote of density and biomass, $\mathrm{ED}_{50}=$ effective dose to elicit a $50 \%$ response, $\mathrm{ED}_{\mathrm{n}}=$ effective dose to elicit response level $n$.

Table 3. Regression parameters and the predicted dose of tolpyralate + atrazine required to obtain $50 \%, 80 \%$, and $95 \%$ control of multiple-herbicide-resistant waterhemp (Amaranthus tuberculatus) 2, 4, 8, and 12 weeks after application (WAA), a 50\%, 80\%, and $95 \%$ reduction in density and biomass, and $50 \%, 80 \%$, and $95 \%$ of the corn grain yield in weed-free control plots, from three field experiments conducted near Cottam, Ontario, Canada in 2018, 2019, and 2020.

\begin{tabular}{|c|c|c|c|c|c|c|}
\hline \multirow[b]{2}{*}{ Variable } & \multicolumn{3}{|c|}{ Regression parameters $^{\mathrm{a}}( \pm \mathrm{SE})$} & \multicolumn{3}{|c|}{ Predicted tolpyralate + atrazine dose } \\
\hline & $a$ & $b$ & $c$ & $\mathrm{ED}_{50}$ & $\mathrm{ED}_{80}$ & $\mathrm{ED}_{95}$ \\
\hline Control & \multicolumn{3}{|c|}{ 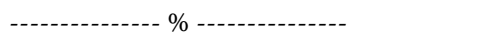 } & \multicolumn{3}{|c|}{ - } \\
\hline $2 \mathrm{WAA}$ & $95(2.7)$ & $26(3.3)$ & - & $4+136$ & $20+671$ & Non-est. \\
\hline $4 \mathrm{WAA}$ & $89(2.9)$ & $24(3.5)$ & - & $5+157$ & $32+1077$ & Non-est. \\
\hline 8 WAA & $91(3.4)$ & $20(3)$ & - & $6+186$ & $33+1112$ & Non-est. \\
\hline \multirow[t]{2}{*}{12 WAA } & $92(3.5)$ & $23(3.7)$ & - & $5+160$ & $28+915$ & Non-est. \\
\hline & \multicolumn{3}{|c|}{ - Plants $\mathrm{m}^{-2}$-...- } & & & \\
\hline \multirow[t]{2}{*}{ Density } & 99 (46.9) & $634(100.2)$ & $0.25(0.1)$ & $3+113$ & $10+339$ & Non-est. \\
\hline & \multicolumn{3}{|c|}{ - } & & & \\
\hline Biomass & $41(14.6)$ & $325(31.5)$ & $0.27(0.06)$ & $3+104$ & $9+292$ & Non-est. \\
\hline Grain yield & $88(4.3)$ & 109 (65.9) & - & $1+35$ & $8+263$ & Non-est. \\
\hline
\end{tabular}

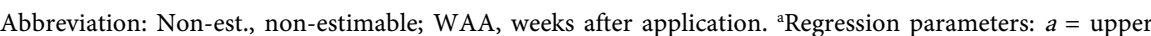
asymptote of control and yield or lower asymptote of density and biomass, $b=$ initial slope of control and yield or reduction in $y$ from intercept to asymptote of density and biomass, $c=$ slope from intercept to lower asymptote of density and biomass, $\mathrm{ED}_{50}=$ effective dose to elicit a $50 \%$ response, $\mathrm{ED}_{\mathrm{n}}=$ effective dose to elicit response level $n$. 
Table 4. Multiple-herbicide-resistant waterhemp (Amaranthus tuberculatus) control at 2, 4, 8, and 12 WAA, percent reduction in density and biomass, and maize grain yield provided by tolpyralate, tolpyralate + atrazine, and two comparison postemergence herbicides from three experiments conducted near Cottam, Ontario, Canada in 2018, 2019, and 2020.

\begin{tabular}{|c|c|c|c|c|c|c|c|c|}
\hline \multirow[b]{2}{*}{ Herbicide treatment ${ }^{\mathrm{a}}$} & \multicolumn{7}{|c|}{ Visible Control } & \multirow[b]{2}{*}{ Corn grain yield } \\
\hline & Rate & 2 WAA & 4 WAA & $8 \mathrm{WAA}$ & 12 WAA & Density & Biomass & \\
\hline & $\mathrm{g}$ ai ha ${ }^{-1}$ & 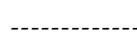 & $-\cdots$ & $-\cdots-\cdot$ & - & Plants $\mathrm{m}^{-2}$ & $g \cdot m^{-2}$ & $\mathrm{~kg} \cdot \mathrm{ha}^{-1}$ \\
\hline Tolpyralate & 30 & $66 \mathrm{ab}$ & $60 \mathrm{a}$ & $60 \mathrm{a}$ & $61 \mathrm{a}$ & $274 \mathrm{ab}$ & $81 \mathrm{ab}$ & $8200 \mathrm{a}$ \\
\hline Tolpyralate + atrazine & $30+1000$ & $78 \mathrm{a}$ & $72 \mathrm{a}$ & $69 \mathrm{a}$ & $71 \mathrm{a}$ & $129 \mathrm{a}$ & $76 \mathrm{a}$ & $8600 \mathrm{a}$ \\
\hline Mesotrione + atrazine & $100+280$ & 79 a & $75 \mathrm{a}$ & $77 \mathrm{a}$ & $78 \mathrm{a}$ & $143 \mathrm{ab}$ & $55 \mathrm{a}$ & $8600 \mathrm{a}$ \\
\hline Dicamba/atrazine & $500 / 1000$ & $60 \mathrm{~b}$ & $69 \mathrm{a}$ & $71 \mathrm{a}$ & $74 \mathrm{a}$ & $140 \mathrm{ab}$ & $70 \mathrm{a}$ & $9200 \mathrm{a}$ \\
\hline Non-treated control & 0 & - & - & - & - & $714 b$ & $360 \mathrm{~b}$ & $4500 \mathrm{~b}$ \\
\hline Weed-free control & $\mathrm{n} / \mathrm{a}$ & - & - & - & - & - & - & $10,300 \mathrm{a}$ \\
\hline
\end{tabular}

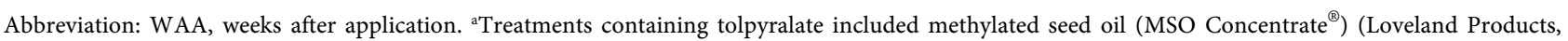
3005 Rocky Mountain Ave., Loveland, CO) (0.50\% v/v) and urea ammonium nitrate (UAN $28-0-0)(2.50 \% \mathrm{v} / \mathrm{v})$. $a-b$ Means within a column followed by the same letter are not statistically different $(\mathrm{P}>0.05)$ using a Tukey-Kramer multiple range test.

Similar to a previous study [38], the addition of atrazine to tolpyralate increased speed of activity in MHR waterhemp, and facilitated a $25 \%$ reduction in the predicted $\mathrm{ED}_{50}$ at Cottam, and an $50 \%$ reduction in the $\mathrm{ED}_{50}$ on Walpole Island at $8 \mathrm{WAA}$, despite the presence of PSI II-resistant biotypes (Table 2, Table 3, Table 5, and Table 6). In contrast, [32] reported no benefit to adding atrazine $\left(560 \mathrm{~g} \cdot \mathrm{ha}^{-1}\right)$ to tolpyralate $\left(40 \mathrm{~g} \cdot \mathrm{ha}^{-1}\right)$ for control of a PS II-resistant Palmer amaranth population. The $\mathrm{ED}_{\mathrm{n}}$ values for tolpyralate and tolpyralate + atrazine were higher for MHR waterhemp 2 WAA than for other Amaranthus species tested in a previous study in Ontario [38]. The $\mathrm{ED}_{50}$ for tolpyralate in green/redroot pigweed was $1.5 \mathrm{~g} \cdot \mathrm{ha}^{-1}$ at 2 WAA [38], while 2 and $5 \mathrm{~g} \cdot \mathrm{ha}^{-1}$ was required to control MHR waterhemp on Walpole Island and at Cottam, respectively, at the same timing. Differences in the $\mathrm{ED}_{50}$ could be attributed to the high density of MHR waterhemp at Cottam compared with Walpole Island and green/redroot pigweed (14 plants $\mathrm{m}^{-2}$ ) [38] or could be indicative of varying sensitivity among Amaranthus species to tolpyralate.

There were differences in MHR waterhemp control 4 WAA with tolpyralate and tolpyralate + atrazine at Cottam and Walpole Island compared to 2 WAA. At Cottam, the $\mathrm{ED}_{50}$ value increased to $6 \mathrm{~g} \cdot \mathrm{ha}^{-1}$ of tolpyralate, and the $\mathrm{ED}_{50}$ and $\mathrm{ED}_{80}$ values increased to $5+157$ and $32+1077 \mathrm{~g} \cdot \mathrm{ha}^{-1}$ of tolpyralate + atrazine. In contrast, control of MHR waterhemp improved on Walpole Island from 2 to 4 WAA; the $\mathrm{ED}_{80}$ decreased by $25 \mathrm{~g} \cdot \mathrm{ha}^{-1}$ and MHR waterhemp was controlled $95 \%$ with $106 \mathrm{~g} \cdot \mathrm{ha}^{-1}$ of tolpyralate alone. The required dose to control MHR waterhemp $50 \%, 80 \%$, and $95 \%$ on Walpole Island decreased at 4 WAA; $20+650$ g.ha ${ }^{-1}$ of tolpyralate + atrazine resulted in $95 \%$ control. These results are inconsistent with [46] who reported $99 \%$ control of EPSPS-resistant waterhemp approximately 4 WAA with tolpyralate applied at $30 \mathrm{~g} \cdot \mathrm{ha}^{-1}$; however, that study evaluated individual plants grown in a controlled greenhouse environment [46]. 
Table 5. Regression parameters and the predicted dose of tolpyralate required to obtain $50 \%, 80 \%$, and $95 \%$ control of multiple-herbicide-resistant waterhemp (Amaranthus tuberculatus) 2, 4, 8, and 12 weeks after application (WAA), a 50\%, 80\%, and 95\% reduction in density and biomass, and $50 \%, 80 \%$, and $95 \%$ of the corn grain yield in weed-free control plots, from four field experiments conducted on Walpole Island, Ontario, Canada in 2018,2019 , and 2020 .

\begin{tabular}{|c|c|c|c|c|c|c|}
\hline \multirow[b]{2}{*}{ Variable } & \multicolumn{3}{|c|}{ Regression parameters ${ }^{\mathrm{a}}( \pm \mathrm{SE})$} & \multicolumn{3}{|c|}{ Predicted tolpyralate dose } \\
\hline & $a$ & $b$ & $c$ & $\mathrm{ED}_{50}$ & $\mathrm{ED}_{80}$ & $\mathrm{ED}_{95}$ \\
\hline Control & \multicolumn{3}{|c|}{ - } & \multicolumn{3}{|c|}{ 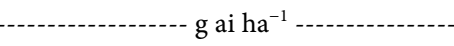 } \\
\hline 2 WAA & $83(3.3)$ & $61(19.9)$ & - & 2 & 34 & Non-est. \\
\hline 4 WAA & $97(2.1)$ & $51(7.1)$ & - & 2 & 9 & 106 \\
\hline 8 WAA & $100(0)$ & $65(7.7)$ & - & 2 & 6 & 29 \\
\hline \multirow[t]{2}{*}{12 WAA } & $100(0)$ & $69(9.1)$ & - & 2 & 6 & 28 \\
\hline & \multicolumn{6}{|c|}{ - } \\
\hline \multirow[t]{2}{*}{ Density } & $1.6(6.7)$ & $93(13.9)$ & $0.23(0.08)$ & 3 & 7 & 15 \\
\hline & \multicolumn{6}{|c|}{ - } \\
\hline Biomass & $0.2(4.2)$ & $90(9.3)$ & $0.35(0.1)$ & 2 & 5 & 9 \\
\hline Grain yield & $105(6.1)$ & $319(489)$ & - & Non-est. & Non-est & 3 \\
\hline
\end{tabular}

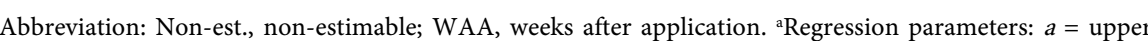
asymptote of control and yield or lower asymptote of density and biomass, $b=$ initial slope of control and yield or reduction in $y$ from intercept to asymptote of density and biomass, $c=$ slope from intercept to lower asymptote of density and biomass, $\mathrm{ED}_{50}=$ effective dose to elicit a $50 \%$ response, $\mathrm{ED}_{\mathrm{n}}=$ effective dose to elicit response level $n$.

Table 6. Regression parameters and the predicted dose of tolpyralate + atrazine required to obtain $50 \%, 80 \%$, and $95 \%$ control of multiple-herbicide-resistant waterhemp (Amaranthus tuberculatus) 2, 4, 8, and 12 weeks after application (WAA), a 50\%, 80\%, and $95 \%$ reduction in density and biomass, and $50 \%, 80 \%$, and $95 \%$ of the corn grain yield in weed-free control plots, from four field experiments conducted on Walpole Island, Ontario, Canada in 2018, 2019, and 2020.

\begin{tabular}{|c|c|c|c|c|c|c|}
\hline & \multicolumn{3}{|c|}{ Regression parameters ${ }^{\mathrm{a}}( \pm \mathrm{SE})$} & \multicolumn{3}{|c|}{ Predicted tolpyralate + atrazine dose } \\
\hline Variable & a & $b$ & $c$ & $\mathrm{ED}_{50}$ & $\mathrm{ED}_{80}$ & $\mathrm{ED}_{95}$ \\
\hline Control & \multicolumn{3}{|c|}{ 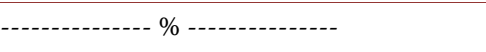 } & \multicolumn{3}{|c|}{ - } \\
\hline $2 \mathrm{WAA}$ & $98(1.7)$ & $84(13.5)$ & - & $1+41$ & $5+176$ & $42+1,432$ \\
\hline 4 WAA & $100(1.4)$ & $100(14.2)$ & - & $1+33$ & $4+134$ & $20+650$ \\
\hline 8 WAA & $100(1.2)$ & $146(24.9)$ & - & $1+23$ & $3+93$ & $13+465$ \\
\hline \multirow[t]{2}{*}{$12 \mathrm{WAA}$} & $100(1.2)$ & $163(29.1)$ & - & $1+21$ & $3+82$ & $12+396$ \\
\hline & \multicolumn{2}{|c|}{ - } & \multirow[b]{2}{*}{$0.35(0.12)$} & \multirow[b]{2}{*}{$2+68$} & \multirow[b]{2}{*}{$5+161$} & \multirow[b]{2}{*}{$10+331$} \\
\hline Density & $1.8(5.2)$ & $92(11.7)$ & & & & \\
\hline Biomass & $1(2.9)$ & $89(7)$ & $0.71(0.3)$ & $1+33$ & $2+78$ & $5+153$ \\
\hline Grain yield & $99(6.2)$ & $627(2040.4)$ & - & Non-est. & Non-est. & $4+119$ \\
\hline
\end{tabular}

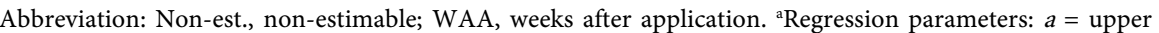
asymptote of control and yield or lower asymptote of density and biomass, $b=$ initial slope of control and yield or reduction in $y$ from intercept to asymptote of density and biomass, $c=$ slope from intercept to lower asymptote of density and biomass, $\mathrm{ED}_{50}=$ effective dose to elicit a $50 \%$ response, $\mathrm{ED}_{\mathrm{n}}=$ effective dose to elicit response level $n$. 
In contrast, [32] reported 96\% control of an ALS-, PS II-, and EPSPS-resistant Palmer amaranth biotype with tolpyralate $\left(40 \mathrm{~g} \cdot \mathrm{ha}^{-1}\right)$ in a field experiment conducted using a similar methodology to this study.

Control of MHR waterhemp decreased further at Cottam and increased on Walpole Island at 8 WAA. Reductions in MHR waterhemp control at Cottam with tolpyralate and tolpyralate + atrazine can be attributed to the extended emergence pattern of waterhemp described by [8]. At Cottam, the predicted dose of tolpyralate and tolpyralate + atrazine for $50 \%$ MHR waterhemp control was $8 \mathrm{~g} \cdot \mathrm{ha}^{-1}$ and $6+186 \mathrm{~g} \cdot \mathrm{ha}^{-1}$, respectively at $8 \mathrm{WAA}$; the predicted dose of tolpyralate + atrazine for $80 \%$ MHR waterhemp control was $33+1112 \mathrm{~g} \cdot \mathrm{ha}^{-1}$ at 8 WAA. Similar to earlier assessment timings, no dose of tolpyralate alone $(\leq 120$ $\mathrm{g} \cdot \mathrm{ha}^{-1}$ ) resulted in $80 \%$ or $95 \%$ control of MHR waterhemp and no dose of tolpyralate + atrazine $\left(\leq 120+\leq 4000 \mathrm{~g} \cdot \mathrm{ha}^{-1}\right)$ resulted in $95 \%$ control at Cottam. In contrast, there was a further decrease in the predicted tolpyralate dose to control MHR waterhemp 50\%, 80\% and $95 \%$ on Walpole Island to 2, 6 and 29 g.ha ${ }^{-1}$, respectively at $8 \mathrm{WAA}$. When applied in combination with atrazine, the $\mathrm{ED}_{50}$ of tolpyralate was reduced from 8 to $6 \mathrm{~g} \cdot \mathrm{ha}^{-1}$ at Cottam and the $\mathrm{ED}_{95}$ of tolpyralate was reduced from 29 to $13 \mathrm{~g} \cdot \mathrm{ha}^{-1}$ on Walpole Island. Osipitan et al. [27] reported similar reductions in the dose of tolpyralate required to control non-herbicide resistant waterhemp $90 \%$ at 60 days after treatment. In that study, the dose of tolpyralate was reduced from 31 to $16 \mathrm{~g} \cdot \mathrm{ha}^{-1}$ when applied in combination with a constant rate of atrazine (560 g.ha ${ }^{-1}$ ) [27]. Tolpyralate + atrazine applied at $13+$ $465 \mathrm{~g} \cdot \mathrm{ha}^{-1}$ resulted in 95\% MHR waterhemp control 8 WAA on Walpole Island. Similar to MHR waterhemp control on Walpole Island, [38] reported 80\% control of green/redroot pigweed with tolpyralate $\left(8.5 \mathrm{~g} \cdot \mathrm{ha}^{-1}\right)$ at $8 \mathrm{WAA}$.

The corn crop at Cottam and on Walpole Island reached physiological maturity and began to dry down by 12 WAA. This assessment timing provided an indication of full-season MHR waterhemp control; previous studies have not evaluated the efficacy of tolpyralate beyond 8 WAA [27] [32] [36] [38] [39]. At Cottam, the predicted dose of tolpyralate for $50 \%$ MHR waterhemp control was $8 \mathrm{~g} \cdot \mathrm{ha}^{-1}$ at $12 \mathrm{WAA}$. Similar to the previous assessment timings, no dose of tolpyralate alone $\left(\leq 120 \mathrm{~g} \cdot \mathrm{ha}^{-1}\right)$ resulted in $80 \%$ or $95 \%$ MHR waterhemp control, and no dose of tolpyralate + atrazine $\left(\leq 120+\leq 4000 \mathrm{~g} \cdot \mathrm{ha}^{-1}\right)$ resulted in $95 \%$ control at Cottam 12 WAA. In contrast, tolpyralate $\left(28 \mathrm{~g} \cdot \mathrm{ha}^{-1}\right)$ and tolpyralate + atrazine $\left(12+396 \mathrm{~g} \cdot \mathrm{ha}^{-1}\right)$, applied below the label rate $\left(40 \mathrm{~g} \cdot \mathrm{ha}^{-1}\right)$ [41], were the predicted doses for $95 \%$ MHR waterhemp control on Walpole Island 12 WAA.

Variation in MHR waterhemp control can be partially attributed to differences in plant density and biomass between Cottam and Walpole Island. At Cottam, $50 \%$ reduction in MHR waterhemp density and biomass resulted from the application of tolpyralate at 6 and $4 \mathrm{~g} \cdot \mathrm{ha}^{-1}$, respectively. Similar to MHR waterhemp control, $80 \%$ and $95 \%$ reductions in MHR waterhemp density and biomass were not achieved with the application of tolpyralate $\left(\leq 120 \mathrm{~g} \cdot \mathrm{ha}^{-1}\right)$, and $95 \%$ reductions did not result from the application of tolpyralate + atrazine 
$\left(\leq 120+\leq 4000 \mathrm{~g} \cdot \mathrm{ha}^{-1}\right)$ at Cottam. The application of $10+339$ and $9+292 \mathrm{~g} \cdot \mathrm{ha}^{-1}$ resulted in an $80 \%$ reduction in MHR waterhemp density and biomass at Cottam. In contrast, MHR waterhemp density and biomass were reduced $95 \%$ with tolpyralate applied at 15 and $9 \mathrm{~g} \cdot \mathrm{ha}^{-1}$, and tolpyralate + atrazine applied at $10+$ 331 and $5+153 \mathrm{~g} \cdot \mathrm{ha}^{-1}$, respectively, on Walpole Island. The addition of atrazine to tolpyralate improved MHR waterhemp control which translated into greater reductions in density and biomass compared to tolpyralate alone at Cottam and on Walpole Island. Metzger et al. [38] reported similar improvements in control and reductions in density and biomass of several grass and broadleaf weed species with the addition of atrazine to tolpyralate. The lower predicted doses for a $50 \%, 80 \%$ and $95 \%$ reduction in biomass compared to density at 8 WAA can be attributed to the extended emergence pattern of MHR waterhemp; there were more waterhemp plants but they were smaller in size as the season progressed.

Reductions in corn grain yield resulted from season-long MHR waterhemp interference and were not the product of early-season corn injury. This is consistent with previous studies that reported good tolerance of corn to HPPD-inhibitors [26] [33]. MHR waterhemp interference in the nontreated controls reduced corn grain yield $56 \%$ and $13 \%$ at Cottam and on Walpole Island, respectively (Table 4 and Table 7). At Cottam, tolpyralate applied alone at 1 and $31 \mathrm{~g} \cdot \mathrm{ha}^{-1}$ was sufficient to maintain $50 \%$ and $80 \%$ corn grain yield relative to the weed-free control, respectively. The application of tolpyralate did not maintain yield $\geq 95 \%$ of the weed-free control; therefore, $\mathrm{ED}_{95}$ could not be calculated at Cottam. In contrast, corn grain yield was never less than $80 \%$ of the weed-free control on Walpole Island; therefore, the $\mathrm{ED}_{50}$ and $\mathrm{ED}_{80}$ could not be calculated and tolpyralate at 3 g.ha ${ }^{-1}$ was sufficient to maintain $95 \%$ yield. Consistent with control assessments, a lower dose of tolpyralate was required when applied in combination with atrazine. At Cottam, tolpyralate + atrazine applied at $8+263 \mathrm{~g} \cdot \mathrm{ha}^{-1}$ resulted in $80 \%$

Table 7. Multiple herbicide-resistant waterhemp (Amaranthus tuberculatus) control at 2, 4, 8, and 12 WAA, percent reduction in density and biomass, and corn grain yield provided by tolpyralate, atrazine + tolpyralate, and two comparison postemergence herbicides from four experiments conducted on Walpole Island, Ontario, Canada in 2018, 2019, and 2020.

\begin{tabular}{|c|c|c|c|c|c|c|c|c|}
\hline \multirow{2}{*}{ Herbicide treatment } & \multirow{2}{*}{ Rate } & \multicolumn{4}{|c|}{ Visible Control } & \multirow{2}{*}{ Density } & \multirow{2}{*}{ Biomass } & \multirow{2}{*}{$\begin{array}{c}\text { Maize grain } \\
\text { yield }\end{array}$} \\
\hline & & 2 WAA & 4 WAA & $8 \mathrm{WAA}$ & $12 \mathrm{WAA}$ & & & \\
\hline & g ai ha ${ }^{-1}$ & - & - & 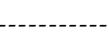 & (n) & Plants $\mathrm{m}^{-2}$ & $\mathrm{~g} \cdot \mathrm{m}^{-2}$ & $\mathrm{~kg} \cdot \mathrm{ha}^{-1}$ \\
\hline Tolpyralate & 30 & $78 \mathrm{a}$ & $91 \mathrm{ab}$ & $96 \mathrm{a}$ & $98 \mathrm{a}$ & $2 \mathrm{ab}$ & $1 \mathrm{ab}$ & $10,500 \mathrm{a}$ \\
\hline Tolpyralate + atrazine & $30+1000$ & 94 a & 98 a & 99 a & 99 a & $0 \mathrm{a}$ & $0 \mathrm{a}$ & $10,100 \mathrm{a}$ \\
\hline Mesotrione + atrazine & $100+280$ & $90 \mathrm{a}$ & $93 \mathrm{ab}$ & $95 \mathrm{a}$ & $98 \mathrm{a}$ & $2 \mathrm{ab}$ & $1 \mathrm{ab}$ & $10,400 \mathrm{a}$ \\
\hline Dicamba/atrazine & $500 / 1000$ & $65 \mathrm{a}$ & $80 \mathrm{~b}$ & $88 \mathrm{a}$ & $91 \mathrm{~b}$ & $8 \mathrm{~b}$ & $8 \mathrm{~b}$ & $9500 \mathrm{a}$ \\
\hline Non-treated control & 0 & - & - & - & - & $96 c$ & $99 \mathrm{c}$ & $9100 \mathrm{a}$ \\
\hline Weed-free control & $\mathrm{n} / \mathrm{a}$ & - & - & - & - & - & - & $10,400 \mathrm{a}$ \\
\hline
\end{tabular}

Abbreviation: WAA, weeks after application. ${ }^{a}$ Treatments containing tolpyralate included methylated seed oil (MSO Concentrate ${ }^{\circledR}$ ) (Loveland Products, 3005 Rocky Mountain Ave., Loveland, CO) (0.50\% v/v) and urea ammonium nitrate (UAN 28-0-0) (2.50\% v/v). a-c Means within a column followed by the same letter are not statistically different $(\mathrm{P}>0.05)$ using a Tukey-Kramer multiple range test. 
yield of the weed-free control. In contrast, tolpyralate + atrazine applied at $4+$ $119 \mathrm{~g} \cdot \mathrm{ha}^{-1}$ was sufficient to maintain $95 \%$ yield on Walpole Island. These results are consistent with [27] who reported $95 \%$ yield was maintained with tolpyralate applied at $36 \mathrm{~g} \cdot \mathrm{ha}^{-1}$ alone and at $28 \mathrm{~g} \cdot \mathrm{ha}^{-1}$ when applied in a tank-mixture with atrazine. Tolpyralate and tolpyralate + atrazine both resulted in excellent control of MHR waterhemp on Walpole Island, which may be why the addition of atrazine did not reduce the tolpyralate dose required to maintain $95 \%$ yield.

\subsection{Tolpyralate, Tolpyralate plus Atrazine, and Comparison Herbicides}

Least-square means of each assessment parameter for tolpyralate applied at 30 g.ha ${ }^{-1}$, representing the low label rate [41], or with atrazine at $1000 \mathrm{~g} \cdot \mathrm{ha}^{-1}$, representing a 1:33.3 tank-mix ratio, were compared to determine the effect of the addition of atrazine to tolpyralate for control of MHR waterhemp. Tolpyralate and tolpyralate + atrazine were compared to dicamba/atrazine (500/1000 $\left.\mathrm{g} \cdot \mathrm{ha}^{-1}\right)$ and mesotrione + atrazine $\left(100+280 \mathrm{~g} \cdot \mathrm{ha}^{-1}\right)$, which represent comparison POST herbicides for control of MHR waterhemp in Ontario [20] [21] [25].

Control of MHR waterhemp ranged from $61 \%$ to $79 \%$ at Cottam (Table 4) and $65 \%$ to $99 \%$ on Walpole Island (Table 7). At Cottam, tolpyralate + atrazine and mesotrione + atrazine resulted in greater control of MHR waterhemp than dicamba/atrazine at 2 WAA. These findings are consistent with [33] who reported $87 \%$ to $98 \%$ control of a PS II-susceptible waterhemp population with mesotrione + atrazine $\left(105+280\right.$ g.ha $\left.{ }^{-1}\right) 10$ days after application. Khort and Sprague [32] also reported $88 \%$ to $96 \%$ control of MHR Palmer amaranth with topramezone (18 g.ha- $\left.{ }^{-1}\right)$, another pyrazolone herbicide, at 2 WAA. On Walpole Island, tolpyralate + atrazine controlled MHR waterhemp 98\% and was greater than dicamba/atrazine; however, control was similar to tolpyralate alone which resulted in $91 \%$ control 4 WAA. Vyn et al. [25] reported $88 \%$ to $91 \%$ control of ALS- and PS II-resistant waterhemp with dicamba/atrazine; however, control was similar to mesotrione + atrazine at 4 and 10 WAA. On Walpole Island, tolpyralate, tolpyralate + atrazine, and mesotrione + atrazine controlled MHR waterhemp $98 \%$ to $99 \%$ which was greater than dicamba/atrazine (91\%) at 12 WAA. These results complement [32] who reported no difference in control of PS II-resistant Palmer amaranth between tolpyralate and tolpyralate + atrazine 3 WAA; however, a higher rate of tolpyralate $\left(40 \mathrm{~g} \cdot \mathrm{ha}^{-1}\right)$ and lower rate of atrazine $\left(560 \mathrm{~g} \cdot \mathrm{ha}^{-1}\right)$ were used in that study. In addition, that population had a similar proportion of PS II-resistant individuals (39\%) as Cottam (54\%) and Walpole Island (30\%) [32]. Though not statistically significant, the addition of atrazine to tolpyralate increased control of MHR waterhemp numerically $1 \%$ to $16 \%$ across all sites which likely would have biological and agronomic implications for subsequent growing seasons given the high fecundity of waterhemp [47]. A similar study by [36] reported tolpyralate, tolpyralate + atrazine, and mesotrione + atrazine applied POST each resulted in similar control of green/redroot pigweed $(\geq 91 \%)$ 
at 8 WAA. In contrast, [27] reported greater control of non-herbicide resistant waterhemp with tolpyralate + atrazine compared to tolpyralate alone. Greater control in that study could be due to the lack of PS II-inhibitor resistance [27].

Density and biomass of MHR waterhemp was greater at Cottam than on Walpole Island. At Cottam, tolpyralate, tolpyralate + atrazine, mesotrione + atrazine, and dicamba/atrazine reduced MHR waterhemp density and biomass $61 \%$ to $82 \%$ and $78 \%$ to $85 \%$, respectively, there was no difference among the four herbicides. On Walpole Island, tolpyralate, tolpyralate + atrazine, mesotrione + atrazine, and dicamba/atrazine reduced MHR waterhemp density and biomass $92 \%$ to $100 \%$; tolpyralate + atrazine reduced MHR waterhemp density and biomass more than dicamba/atrazine. Reductions in MHR waterhemp density and biomass were similar between tolpyralate and tolpyralate + atrazine at all sites which can be expected given similar control between these treatments at $2,4,8$, and 12 WAA. Tolpyralate alone provided similar reductions in MHR waterhemp density and biomass compared to both comparison POST herbicides. Khort and Sprague [32] reported similar reductions in the biomass of PS II-resistant Palmer amaranth with tolpyralate, tolpyralate + atrazine, and mesotrione + atrazine at 3 WAA. Despite the limited residual activity of tolpyralate [41], control data at 8 and 12 WAA coupled with density and biomass data indicate that tolpyralate may provide residual control of late-emerging waterhemp cohorts.

Interference of MHR waterhemp reduced corn grain yield 56\% in the nontreated controls at Cottam; there was no yield loss detected on Walpole Island due to MHR waterhemp. Waterhemp is highly competitive with corn [18]; however, [25] also reported differences between sites regarding the effect of season-long MHR waterhemp interference on yield. Compared to Walpole Island, corn grain yield loss at Cottam can be attributed to greater MHR waterhemp density and biomass, and a greater proportion of herbicide resistant individuals at Cottam.

\section{Conclusion}

The predicted dose of tolpyralate and tolpyralate + atrazine for $50 \%, 80 \%$, and 95\% MHR waterhemp control varied with waterhemp density, biomass, and population resistance profile. The predicted doses of tolpyralate for $50 \% \mathrm{MHR}$ waterhemp control were 8 and $2 \mathrm{~g} \cdot \mathrm{ha}^{-1}$ at Cottam and on Walpole Island, respectively at 12 WAA; no dose of tolpyralate alone resulted in $80 \%$ or $95 \%$ control at Cottam. Applied at the currently registered rate of $30 \mathrm{~g} \cdot \mathrm{ha}^{-1}$, tolpyralate controlled MHR waterhemp $60 \%$ to $98 \%$ across sites and was similar to mesotrione + atrazine at 2, 4, 8, and 12 WAA. Despite resistance to PS II-inhibitors, the addition of atrazine to tolpyralate at a 1:33.3 ratio numerically improved control of MHR waterhemp 2, 4, 8, and 12 WAA; however, this was non-significant. Similarly, the addition of atrazine to tolpyralate resulted in lower $\mathrm{ED}_{50}, \mathrm{ED}_{80}$, and $\mathrm{ED}_{95}$ doses than tolpyralate alone. These results complement [27] who reported 
greater MHR waterhemp control when tolpyralate and atrazine were applied in a POST tank-mixture compared to tolpyralate alone. In contrast, these results are conflicting with a previous study of the biologically-effective-dose (BED) of tolpyralate [38], which found similar BED values for tolpyralate in green/redroot pigweed when applied alone or with atrazine. Similarly, the addition of atrazine to tolpyralate at the label rate did not improve control of green/redroot pigweed 2 or 4 WAA in that study, possibly indicating that green/redroot pigweed is comparatively more sensitive to tolpyralate than waterhemp. Across all assessment parameters except 2 WAA at Cottam and 12 WAA on Walpole Island, tolpyralate and tolpyralate + atrazine controlled MHR waterhemp similar to mesotrione + atrazine and dicamba/atrazine. Though non-significant, tolpyralate + atrazine and mesotrione + atrazine resulted in the greatest control of MHR waterhemp across all sites, substantiating previous reports of excellent POST control of this species in corn with HPPD- + PS II-inhibitor tank-mixtures [19] [20] [21] [25]. As a result of high MHR waterhemp density and biomass, corn grain yield was reduced by $56 \%$ at Cottam which is of economic significance. The application of tolpyralate and tolpyralate + atrazine resulted in similar yield to dicamba/atrazine and mesotrione + atrazine. Overall, this study demonstrates that tolpyralate and tolpyralate + atrazine applied at the current label rate can result in season-long control MHR waterhemp and maintain corn yield. Identifying alternative herbicide tank-mixtures to manage a competitive weed species such as MHR waterhemp is crucial given its ability to rapidly evolve herbicide-resistance and stack traits that confer resistance to multiple MOA. Populations of MHR waterhemp have been identified with resistance to the HPPD-inhibitors [14]. To ensure future use of tolpyralate and other HPPD-inhibitors, these herbicides should be used in combination with best management practices such as herbicide-rotation, tank-mixing multiple-effective MOA, crop rotation, strategic tillage, and cover crops to ensure the longevity of these products for weed management in corn-based cropping systems.

\section{Acknowledgements}

The authors would like to acknowledge Chris Kramer for his technical assistance, Dr. Michelle Edwards for her statistical support, the University of Guelph, Ridgetown Campus summer staff for their field support and Grain Farmers of Ontario for providing funding for this research.

\section{Conflicts of Interest}

The authors declare no conflicts of interest regarding the publication of this paper.

\section{References}

[1] Heap, I. (2020) The International Survey of Herbicide Resistant Weeds. http://www.weedscience.org

[2] Benoit, L., Hedges, B., Schryver, M.G., Soltani, N., Hooker, D.C., Robinson, D.E., 
Laforest, M., Soufiane, B., Tranel, P.J., Giacomini, D. and Sikkema, P.H. (2020) The First Record of Protoporphyrinogen Oxidase and Four-Way Herbicide Resistance in Eastern Canada. Canadian Journal of Plant Science, 100, 327-331. https://doi.org/10.1139/cjps-2018-0326

[3] Costea, M., Weaver, S.E. and Tardif, F.J. (2005) The Biology of Invasive Alien Plants in Canada. 3. Amaranthus tuberculatus (Moq.) Sauer var. rudis (Sauer) Costea \& Tardif. Canadian Journal of Plant Science, 85, 507-522. https://doi.org/10.4141/P04-101

[4] Hartzler, R.G., Battles, B.A. and Nordby, D. (2004) Effect of Common Waterhemp (Amaranthus rudis) Emergence Date on Growth and Fecundity in Soybean. Weed Science, 52, 242-245. https://doi.org/10.1614/WS-03-004R

[5] Wu, C. and Owen, M.D.K. (2014) When Is the Best Time to Emerge: Reproductive Phenology and Success of Natural Common Waterhemp (Amaranthus rudis) Cohorts in the Midwest United States? Weed Science, 62, 107-117. https://doi.org/10.1614/WS-D-13-00079.1

[6] Leon, R.G. and Owen, M.D.K. (2003) Regulation of Weed Seed Dormancy through Light Temperature Interactions. Weed Science, 51, 752-758.

https://doi.org/10.1614/P2002-173

[7] Leon, R.G., Bassham, D.C. and Owen, M.D.K. (2006) Germination and Proteome Analyses Reveal Intraspecific Variation in Seed Dormancy Regulation in Common Waterhemp (Amaranthus tuberculatus). Weed Science, 54, 305-315. https://doi.org/10.1614/WS-05-115R1.1

[8] Schryver, M.G., Soltani, N., Hooker, D.C., Robinson, D.E., Tranel, P.J. and Sikkema, P.H. (2017) Glyphosate-Resistant Waterhemp (Amaranthus tuberculatus var. rudis) in Ontario, Canada. Canadian Journal of Plant Science, 97, 1057-1067. https://doi.org/10.1139/CJPS-2016-0371

[9] Vyn, J.D., Swanton, C.J., Weaver, S.E. and Sikkema, P. (2007) Control of Herbicide-Resistant Common Waterhemp (Amaranthus tuberculatus var. rudis) with Pre- and Post-Emergence Herbicides in Soybean. Canadian Journal of Plant Science, 87, 175-182. https://doi.org/10.4141/P06-016

[10] Nordby, D., Hartzler, B. and Bradley, K. (2007) Biology and Management of Waterhemp. The Glyphosate, Weeds and Crops Series No. 13. Purdue Extension.

[11] Kreiner, J.M., Glacomini, D.A., Bemm, F., Walthaka, B., Regaldao, J., Lanz, C., Hildebrandt, J., Sikkema, P.H., Tranel, P.J., Weigel, D., Stinchcombe, J.R. and Wright, S.I. (2018) Multiple Modes of Convergent Adaptation in the Spread of Glyphosate-Resistant Amaranthus tuberculatus. Proceedings of the National Academy of Sciences of the United States of America, 116, 21076-21084. https://doi.org/10.1073/pnas.1900870116

[12] Liu, J., Davis, A.S. and Tranel, P.J. (2012) Pollen Biology and Dispersal Dynamics in Waterhemp (Amaranthus tuberculatus). Weed Science, 60, 416-422. https://doi.org/10.1614/WS-D-11-00201.1

[13] Bell, M.S., Hager, A.G. and Tranel, P.J. (2013) Multiple Resistance to Herbicides from Four Site-of-Action Groups in Waterhemp (Amaranthus tuberculatus). Weed Science, 61, 460-468. https://doi.org/10.1614/WS-D-12-00166.1

[14] McMullan, P.M. and Green, J.M. (2011) Identification of a Tall Waterhemp (Amaranthus tuberculatus) Biotype Resistant to HPPD-Inhibiting Herbicides, Atrazine, and Thifensulfuron in Iowa. Weed Technology, 25, 514-518. https://doi.org/10.1614/WT-D-10-00150.1 
[15] Shergill, L., Barlow, B., Bish, M. and Bradley, K. (2018) Investigations of 2,4-D and Multiple Herbicide Resistance in a Missouri Waterhemp (Amaranthus tuberculatus) Population. Weed Science, 66, 386-394. https://doi.org/10.1017/wsc.2017.82

[16] Jhala, A.J., Norsworthy, J.K., Gaine, Z.A., Sosnoskie, L.M., Beckie, H.J., Mallory-Smith, C.A., Liu, J., Wei, W., Wang, J. and Stoltenberg, D.E. (2020) Pollen-Mediated Gene Flow and Transfer of Resistance Alleles from Herbicide-Resistant Broadleaf Weeds. Weed Technology. (In Press) https://doi.org/10.1017/wet.2020.101

[17] Sarangi, D., Tyre, A.J., Patterson, E.L., Gaines, T.A., Irmak, S., Knezevic, S.Z., Lindquist, J.L. and Jhala, A.J. (2017) Pollen-Mediated Gene Flow from Glyphosate-Resistant Common Waterhemp (Amaranthus rudis Sauer): Consequences for the Dispersal of Resistance Genes. Scientific Reports, 7, Article No. 44913. https://doi.org/10.1038/srep44913

[18] Steckel, L.E. and Sprague, C.L. (2004) Common Waterhemp (Amaranthus rudis) Interference in Corn. Weed Science, 52, 359-364.

https://doi.org/10.1614/WS-03-066R1

[19] Soltani, N., Vyn, J.D. and Sikkema, P. (2009) Control of Common Waterhemp (Amaranthus tuberculatus var. rudis) in Corn and Soybean with Sequential Herbicide Applications. Canadian Journal of Plant Science, 89, 127-132. https://doi.org/10.4141/CJPS08051

[20] Benoit, L., Soltani, N., Hooker, D.C., Robinson, D.E. and Sikkema, P.H. (2019) Control of Multiple-Resistant Waterhemp [Amaranthus tuberculatus (Moq.) Sauer] with Preemergence and Postemergence Herbicides in Corn in Ontario. Canadian Journal of Plant Science, 99, 364-370. https://doi.org/10.1139/cjps-2018-0087

[21] Benoit, L., Soltani, N., Hooker, D.C., Robinson, D.E. and Sikkema, P.H. (2019) Efficacy of HPPD-Inhibiting Herbicides Applied Preemergence or Postemergence for Control of Multiple Herbicide Resistant Waterhemp [Amaranthus tuberculatus (Moq.) Sauer]. Canadian Journal of Plant Science, 99, 379-383.

https://doi.org/10.1139/cjps-2018-0320

[22] Hedges, B.K., Soltani, N., Hooker, D.C., Robinson, D.E. and Sikkema, P.H. (2018) Control of Glyphosate-Resistant Waterhemp with Two-Pass Weed Control Strategies in Glyphosate/Dicamba-Resistant Soybean. American Journal of Plant Sciences, 9, 1424-1432. https://doi.org/10.4236/ajps.2018.97104

[23] Jhala, A.J., Sandell, L.D., Sarangi, D., Kruger, G.R. and Knezevic, S.Z. (2017) Control of Glyphosate-Resistant Common Waterhemp (Amaranthus rudis) in Glufosinate-Tolerant Soybean. Weed Technology, 31, 32-45.

https://doi.org/10.1017/wet.2016.8

[24] Schryver, M.G., Soltani, N., Hooker, D.C., Robinson, D.E., Tranel, P.J. and Sikkema, P.H. (2017) Control of Glyphosate-Resistant Waterhemp (Amaranthus tuberculatus var. rudis) with Dicamba and Dimethenamid-P in Ontario. Canadian Journal of Plant Science, 98, 362-369. https://doi.org/10.1139/CJPS-2017-0052

[25] Vyn, J.D., Swanton, C.J., Weaver, S.E. and Sikkema, P.H. (2006) Control of Amaranthus tuberculatus var. rudis (Common Waterhemp) with Pre- and Post-Emergence Herbicides in Zea mays L. (Maize). Journal of Crop Protection, 25, 1051-1056. https://doi.org/10.1016/j.cropro.2006.01.016

[26] Mitchell, G., Bartlett, D.W., Fraser, T.E.M., Hawkes, T.R., Holt, D.C., Townson, J.K. and Wichert, R.A. (2001) Mesotrione: A New Selective Herbicide for Use in Maize. Pest Management Science, 57, 120-128. https://doi.org/10.1002/1526-4998(200102)57:2<120::AID-PS254>3.0.CO;2-E 
[27] Osipitan, O.A., Scott, J.E. and Knezevic, S.Z. (2018) Tolpyralate Applied Alone and with Atrazine for Weed Control in Corn. The Journal of Agricultural Science, 10, 32-39. https://doi.org/10.5539/jas.v10n10p32

[28] Sarangi, D. and Jhala, A.J. (2017) Biologically Effective Rates of a New Premix (Atrazine, Bicyclopyrone, Mesotrione, and S-Metolachlor) for Preemergence or Postemergence Control of Common Waterhemp [Amaranthus tuberculatus (Moq.) Sauer var. rudis] in Corn. Canadian Journal of Plant Science, 97, 1075-1089. https://doi.org/10.1139/CJPS-2017-0037

[29] Willemse, C., Soltani, N., Benoit, L., Hooker, D.C., Jhala, A.J., Robinson, D.E. and Sikkema, P.H. (2020) Herbicide Programs for Control of Waterhemp (Amaranthus tuberculatus) Resistant to Three Distinct Herbicide Sites of Action in Corn. Weed Technology. (In Press) https://doi.org/10.1017/wet.2020.140

[30] Williams, M.M., Boydston, R.A., Peachey, R.E. and Robinson, D. (2011) Significance of Atrazine as a Tank-Mix Partner with Tembotrione. Weed Technology, 25, 299-302. https://doi.org/10.1614/WT-D-10-00140.1

[31] Hugie, J.A., Bollero, G.A., Tranel, P.J. and Riechers, D.E. (2008) Defining the Rate Requirements for Synergism between Mesotrione and Atrazine in Redroot Pigweed (Amaranthus retroflexus). Weed Science, 56, 265-270. https://doi.org/10.1614/WS-07-128.1

[32] Khort, J.R. and Sprague, C.L. (2017) Response of a Multiple-Resistant Palmer Amaranth (Amaranthus palmeri) Population to four HPPD-Inhibiting Herbicides Applied Alone and with Atrazine. Weed Science, 65, 534-535. https://doi.org/10.1017/wsc.2017.28

[33] Woodyard, A.J., Bollero, G.A. and Riechers, D.E. (2009) Broadleaf Weed Management in Corn Utilizing Synergistic Postemergence Herbicide Combinations. Weed Technology, 23, 513-518. https://doi.org/10.1614/WT-08-188.1

[34] Armel, G.R., Richardson, R.J., Wilson, H.P. and Hines, T.E. (2009) Strategies for Control of Horseweed (Conyza canadensis) and Other Winter Annual Weeds in No-Till Corn. Weed Technology, 23, 379-383. https://doi.org/10.1614/WT-08-094.1

[35] Hankamer, B., Barber, J. and Boekema, E.J. (1997) Structure and Membrane Organization of Photosystem II in Green Plants. Annual Review of Plant Physiology and Plant Molecular Biology, 48, 641-671. https://doi.org/10.1146/annurev.arplant.48.1.641

[36] Metzger, B.A., Soltani, N., Raeder, A.J., Hooker, D.C., Robinson, D.E. and Sikkema, P.H. (2018) Tolpyralate Efficacy: Part II. Comparison of Three Group 27 Herbicides Applied Postemergence for Annual Grass and Broadleaf Weed Control in Corn. Weed Technology, 32, 707-713. https://doi.org/10.1017/wet.2018.81

[37] Langdon, N.M., Soltani, N., Raeder, A.J., Hooker, D.C., Robinson, D.E. and Sikkema, P.H. (2020) Influence of Adjuvants on the Control of Glyphosate-Resistant Canada Fleabane and Waterhemp in Corn with Tolpyralate. American Journal of Plant Sciences, 11, 354-371. https://doi.org/10.4236/ajps.2020.113026

[38] Metzger, B.A., Soltani, N., Raeder, A.J., Hooker, D.C., Robinson, D.E. and Sikkema, P.H. (2018) Tolpyralate Efficacy: Part I. Biologically-Effective Dose of Tolpyralate for Control of Annual Grass and Broadleaf Weeds in Corn. Weed Technology, 32, 698-706. https://doi.org/10.1017/wet.2018.82

[39] Metzger, B.A., Soltani, N., Raeder, A.J., Hooker, D.C., Robinson, D.E. and Sikkema, P.H. (2019) Effect of Hybrid Varieties, Application Timing, and Herbicide Rate on Field Corn Tolerance to Tolpyralate plus Atrazine. Weed Technology, 67, 475-484. 
https://doi.org/10.1017/wsc.2019.34

[40] Anonymous (2017) Shieldex ${ }^{\circledR}$ 400SC Herbicide Label. SummitAgroUSA, Durham.

[41] Anonymous (2019) Shieldex ${ }^{\circledast}$ 400SC Herbicide Label. ISK Biosciences Corporation, Concord.

[42] Weed Science Society of America (2020) Composite List of Weeds. https://wssa.net/wssa/weed/composite-list-of-weeds

[43] Ontario Ministry of Agriculture, Food and Rural Affairs (OMAFRA) (2018) Publication 75A: Guide to Weed Control in Field Crops 2018. Queen's Printer, Toronto, Ontario.

[44] Cousens, R. (1985) A Simple Model Relating Yield Loss to Weed Density. Annals of Applied Biology, 107, 239-252. https://doi.org/10.1111/j.1744-7348.1985.tb01567.x

[45] Johnson, B.C. and Young, B.G. (2002) Influence of Temperature and Relative Humidity on the Foliar Activity of Mesotrione. Weed Science, 50, 157-161. https://doi.org/10.1614/0043-1745(2002)050[0157:IOTARH]2.0.CO;2

[46] Kikugawa, H., Satake, Y., Tonks, D.J., Grove, M., Nagayama, S. and Tsukamoto, M. (2015) Tolpyralate: New Post-Emergence Herbicide for Weed Control in Corn. Weed Science Society of America Conference Proceedings, Lexington, 9-12 February 2015, 275.

[47] Hartzler, R.G., Buhler, D.D. and Stoltenberg, D.E. (1999) Emergence Characteristics of Four Annual Weed Species. Weed Science, 47, 578-584.

https://doi.org/10.1017/S0043174500092298 